Journal of Southeast Asian Studies, 33 (1), pp 147-162 February 2002. Printed in the United Kingdom.

(๑) 2002 The National University of Singapore

\title{
Between the Global and the Local There Are Regions, Culture Areas, and National States: A Review Article
}

\section{Grant Evans}

History, Culture, and Region in Southeast Asian Perspectives, Revised Edition. By O. W. WOLTERS

Ithaca, NY: Cornell Southeast Asian Program, in cooperation with The Institute of Southeast Asian Studies, 1999. Pp. 272. Maps, Notes, Appendixes, Bibliography, Index.

In 1999, the late O.W. Wolters released a revised edition of his influential, and still stimulating, History, Culture, and Region in Southeast Asian Perspectives. Besides publishing the original 1982 text amounting to 102 pages, he has added a postscript that is equally long where he attempts an assessment of his earlier work in the light of later scholarly developments.

When the essay originally appeared, one could not help but admire its boldness, scope and erudition. Since then, however, the meteoric rise of 'globalisation' studies has perhaps made his scope seem timid, and post-modernism made his analysis of culture seem passé. Regional analysis has been bypassed by the 'global' or outflanked by the 'local', and culture - we are told - is always 'hybrid'. In his Revised Edition Wolters faces the challenge calmly, and maintains his focus on Southeast Asia as a region and as a culture area. There are good reasons for doing so too.

The idea of 'Southeast Asia' received extensive discussion during its definition as a field of 'area studies'. One of the best commentaries was by Donald K. Emmerson in 1984: “Southeast Asia": What's in a Name?', where he suggested that this name simultaneously described and invented a reality. His worry about the 'invented' part of a Southeast Asian reality was that it could project a 'homogeneity, unity, and boundedness onto a part of the world that is in fact heterogeneous, disunited, and hard to delimit'. Like other scholars, ${ }^{2}$ Emmerson quite rightly makes much of the political origins of Southeast Asia, with a major turning point being the Second World War when, as a theatre for war, the region came into focus. Subsequently it became a theatre of the Cold War and that produced a demand for knowledge of the region, especially in the US, and spawned area studies programmes in the universities. Newly independent states in Southeast Asia also began to produce their own studies of their societies and histories. Finally, in 1967 ASEAN emerged as a regional organisation, but the burgeoning hot war Grant Evans is Reader in Anthropology in the Department of Sociology, University of Hong Kong. His email address is Hrnsgre@khucc.hku.hk

1 Donald K. Emmerson, “'Southeast Asia”: What's in a Name?', Journal of Southeast Asian Studies, 15, 1 (1984): 1 .

2 Russell H. Fifield, 'Southeast Asia as a Regional Concept', Southeast Asian Journal of Social Science, 11, 2 (1983): 1-14. 
in Vietnam and its aftermath delayed ASEAN's aim for regional unity until 1999 when Cambodia was admitted. Few would deny that this unity is primarily political, and many comment on its fragility even in this regard now that the former 'enemies' Vietnam, Laos and Cambodia are members, along with Myanmar (Burma).

The creation of 'area studies', however, led people to search for what are deemed 'deeper' cultural unities which, perhaps, can (in Emmerson's words) 'change a cartographic convenience into an entity with an identity internal to itself'. ${ }^{3}$ The 'invention' of a Southeast Asian reality occurred first, he argues, during World War Two when the region was made 'visible'. Second, it legitimated a term, 'Southeast Asia'. Then came the foreign policy concerns of the Cold War: 'by attracting world attention and creating a need to talk about the region, political disunity bolstered the semantic unity of 'Southeast Asia.' There is, therefore, something of a self-fulfilling prophecy at work here that begins to produce, at least at some levels, common meanings across the region.

As within the confines of states themselves, so within the region diversities began to get woven into unities. In a journal forum on 'Reconceptualizing Southeast Asia', Anthony Reid speaks of the historical importance of Chinese networks and of the creation of regional universities for the emergence of a sense of the region. ${ }^{5}$ Other contributors focus on how political and economic exchanges within the region have intensified, along with cultural exchanges in the form of academic gatherings, 'high' cultural events, migration and tourism, and to some extent, pop culture as well. Sports events have also become important arenas for the creation of a sense of regional unity. All of these activities produce a growing sense of 'semantic unity', and indeed cultural unity, to the extent that people from the region begin to identify themselves as, for example, both Malaysian and Southeast Asian.

Despite such developments, however, attempts to find sources of cultural unity in Southeast Asia have rarely focused on the present or on recent history. Its unity, if there, is assumed to be rooted in the past, and hence historians like Wolters have been active in seeking it out.

\section{Southeast Asia as a culture area?}

Wolters' argument is not directly phrased in terms of a culture area, but it certainly tends towards something like it. He claims in the earlier edition to have 'gone a considerable way in substantiating early Southeast Asia's "regional" status by assembling what I proposed were "some widespread cultural traits"... and the experience of writing this postcript has strengthened this opinion'. Thus he proposes 'continuities extending over the centuries', even up to mid-1997. He hastens to add, however, 'that I am convinced as ever that the characteristics of sub-regional, or local, cultures are as significant as the shared cultural traits...'6

There are some important innovative manoeuvres in the new postscript dealing with what Wolters still calls the Southeast Asian 'cultural matrix'. Previously he identified

3 Emmerson, 'Southeast Asia', p. 2.

Ibid., p. 10.

Anthony Reid, 'A Saucer Model of Southeast Asian Identity', Southeast Asian Journal of Social Science, 27, 1 (1999): 7-24.

6 Wolters, History, Culture, and Region, p. 106. 
'men of prowess' possessed of 'soul stuff' as one key element in this matrix, ${ }^{7}$ along with widespread cognatic forms of descent which allegedly encourage non-lineal transmission of power. He keeps these ideas, but influenced by the 'cultural turn' in history he now focuses on processes of meaning formation, especially in relation to the 'Indianization' of Southeast Asia which he prefers to rephrase as 'self-Hinduization', 'because Hinduism, a religious concept, was the crucial Indian phenomenon onto which Southeast Asians latched'.

Wolters makes some important theoretical points about this process of 'selfHinduization' which are generally relevant to the process whereby peoples assimilate 'foreign' cultural traits. Let me cite a key paragraph where he refers to the problem of how people 'make sense' of their world:

By this expression I mean no more than the ability to organize what happens around one in terms of one's previous experience. 'Making sense' is the mental process of understanding new things in the light of existing knowledge by spotting similarities. In this way one can make plausible assumptions. One familiarizes the unfamiliar by mapping the unfamiliar on what is already known. Fitting new experiences into a familiar and often flexible category is another way of 'making sense'. A new experience can also be rendered by using the devices of metaphor or allegory. ${ }^{9}$

Thus local leaders in Southeast Asia, the men of prowess, on coming in contact with Hindu ideas 'gradually construed their own milieu and way of life as verifying what Sanskrit literature... assumed to be universal phenomena... The process of selfHinduization would be facilitated because the texts could often present matters of local common sense as examples of universal wisdom. ${ }^{10}$ Wolters also upgrades the role or power of words spoken by men of prowess in his evaluation of the matrix, and suggests that the impermanence of personalised entourages accounted for a 'present-mindedness' and a cultural openness.

Wolters is pursuing other issues here as well, in particular arguments about the formation of states in early Southeast Asia and their alleged centralisation. Here he presents a strong culturalist argument, saying that a 'single factor', Hinduism, accounts for the rise of states, not the multiple variables listed by archaeologist Charles Higham. I do not want to enter into this argument, except to note that it forms a piece with the way he argues later chapters. ${ }^{11}$

Wolters once again asserts the importance of the mandala-style polity for much of pre-modern Southeast Asia, that is, a polity with fluctuating boundaries centred on a king who radiated 'soul stuff' out of which he constructed a personalised rule. I have no

7 He does, however, suggest one modification to this, although he does not develop it: 'I believe that the prospects facing the concept of men of prowess will have to be reconsidered when Southeast Asia in mandala times becomes a field for extensive gender studies. The expression "men of prowess" and "women of prowess" may need to be abandoned in favor of "people of prowess", and this possibility would have the merit of bringing to the fore the questions of what criteria - political, religious, economic, and so forth - shared by men and women alike were to be associated with the manifestation of extraordinary qualities' (ibid., pp. 169-70).

8 Ibid., p. 110

9 Ibid., p. 109.

10 Ibid., p. 110

11 I should note that Wolters (pp. 122-5) is also swayed by the concept of 'heterarchy' advanced by Joyce White which proposes a 'pluralistic' interpretation of Southeast Asian 'pre-history' (a problematic term). 
quarrel with this general argument, although I would challenge his presentation of Ayudhya which, following Sunait Chutintaranond, he claims simply copied the fluctuating, 'pulsating', mandala model. In fact Sunait himself shows that there were inner circles more closely tied to the king and outer circles to the mandala, and these inner circles have to be seen as a moderate form of centralisation, buttressed by the important economic role of Ayudhya. ${ }^{12}$

More important for my concerns are Wolters' arguments about the 'localization' of foreign cultural elements, something he pursues at the end of his third new chapter, 'Some Further Southeast Asian Perspectives'. Once again he refers to the way Sanskrit materials were 'localized' to become 'a new cultural whole. The process would constitute "a local statement" about something else that the host culture made about itself. ${ }^{13}$ What is, of course, problematic about this statement is: how 'new' is the new cultural whole? The chapter that follows on 'Local Writing' is a very interesting discussion of the way foreign forms were used to make local statements, and indeed he calls for further research that will 'one day help to delineate specific literary cultures and illustrate the phenomenon of cultural diversity. ${ }^{14}$

Departing from historical ruminations, Wolters in his last chapter makes a bold step into the present to re-deploy the concepts he has developed for Southeast Asian history. One can hardly quarrel with the gist of the following passage:

The global market today is the latest instance in world history of a large-scale cultural transformation, whereby a sense of the world in which one lives and therefore one's lifestyle are transformed. One thinks of 'Hinduization', the Reformation, and the scientific revolution (with its responsiveness to the demystification of the world grounded on Reformation ideology) as three such instances. ${ }^{15}$

What is unclear, however, is how we are to judge such transformations. Is what we are witnessing simply the intensification of cultural borrowing today or some more profound change? While I may agree with Wolters that we need to pay attention to local processes when evaluating such borrowings, can we say, as he does, that 'Southeast Asia has now entered its neo-mandala age'? ${ }^{16} \mathrm{He}$ explains that the connecting thread between past and future:

may be a curiosity in the cognitive processes whereby former and present generations of Southeast Asians could construct and reflect on what was and is happening to them. Thus, I have come to believe that mandala and globalisation history in Southeast Asia have something in common. In both cases the scene is multi-centered and boundaryless, and the dominating character is immense prowess, a flexible category capable of accomodating religious, political, or economic power. ${ }^{17}$

12 Sunait Chutintaranond, "Mandala," "Segmentary State” and Politics of Centralization in Medieval Ayudhya, Journal of the Siam Society, 78, 1 (1990): 89-100. An important collection on Ayudhya's relations with the region has recently appeared, which includes an essay by Sunait. See From Japan to Arabia: Ayuthaya's Maritime Relations with Asia, ed. Kennon Breazeale (Bangkok: The Foundation for the Promotion of Social Sciences and Humanities Textbooks, Toyota Thailand Foundation, 1999).

13 Wolters, History, Culture, and Region, p. 173.

14 Ibid., p. 205.

15 Ibid., p. 220

16 Ibid., p. 221.

17 Ibid., p. 221. 
But how continuous are cultural forms over time? How do we avoid the pitfalls of approaches that, as Jack Goody puts it, 'stripped societies down to supposedly continuing elements, to themes and patterns that persisted through all adversity, immaterial components that no bomb could destroy...? ? ${ }^{18}$ I will return to this issue below, but in order to focus on the idea of a cultural area, let me address the question of whether Vietnam is part of a Southeast Asian cultural area or not.

\section{Vietnam and East Asia}

I begin with two flat statements: first, that Vietnam is politically part of Southeast Asia, but second, that it is part of an East Asian cultural area. Of course, historian of Vietnam Keith Taylor in his Birth of Vietnam argues that 'The question of whether Vietnam "belongs" to Southeast Asia or East Asia is probably one of the least enlightening in Vietnamese studies. ${ }^{19}$ Vietnam, he says, is a frontier and a 'blend' of the two - unique, as the Vietnamese often like to imagine themselves. The full implications of such statements are rarely realised by their authors because if we take them logically, then Korea is also unique, as is Japan, and thus East Asia disintegrates while Southeast Asia is left standing! (Though logically the latter should disintegrate as well.) In fact, logically all macro-categories disintegrate into local uniquenesses, and indeed Taylor in his most recent work (which I shall consider below) finds himself absorbed in 'localised' meanings.

Taylor's 1983 work is perhaps the most sophisticated statement available of Vietnamese nationalist historiography. The thrust of it is to assert that despite Sinitic conquest a Vietnamese cultural essence persevered, and perseveres today. The aim of the book is to demonstrate this primordial distinctiveness from 'China'. Of course, in true populist style, it is asserted that only the upper classes were truly Sinicised, and indeed it was the Nguyen, the most Sinitic dynasty, which smothered the cultural essence (a key element of which is supposedly the desire for 'independence') and ensured minimal resistance to French colonialism. Taylor makes many such contentious specific claims in this book, but what interests me is his approach to cultural borrowings.

Here we can also return to Wolters, who says in his revised book that 'Today I do not discern so sharp a contrast between Southeast Asia and Vietnam, at least as late as the thirteenth and fourteenth centuries... ${ }^{20}$ His argument, which is a straightforward empirical issue, is that it was only from the late fourteenth century that the state made a concerted attempt to 'Confucianise' village social behaviour. This was an 'ideological watershed' which 'became in the late fifteenth century and thereafter a permanent "change", though not a change felt always and everywhere.2. Thus, although there was an important difference in state form between Vietnam and the other states of Southeast Asia before this date, the overall difference is even greater after it.

One suspects that the modification of Wolters' view of Vietnam derives from his analysis and interest in local writing, already expressed in the first version of the book and elaborated in the revised version. In the original text he poses the problem of whether there exists a 'Vietnamese' poetry because the forms are all so clearly 'Chinese'.

18 Jack Goody, 'Culture and its Boundaries: a European View', Social Anthropology, 1, 1 (1993): 17.

19 Keith W. Taylor, The Birth of Vietnam (Berkeley: University of California Press, 1983), p. xxi.

20 Wolters, History, Culture, and Region, p. 143.

21 Ibid., p. 146. 
His reply is that, yes, they are Vietnamese because they have been localised in content and would have been vocalised in Vietnamese. And, he writes in his revised edition:

Vietnamese ... came to believe that ancient Chinese classical writing exemplified universal and not simply Chinese patterns of experience, and therefore they did not hesitate to invoke Chinese literary passages as rhetorical flourishes to illustrate their lofty status in the world and to ratify whatever they themselves had to say. ${ }^{22}$

But surely it is precisely this that locates the Vietnamese so firmly in an East Asian Sinitic - cultural universe: that is, their acceptance that it is only through these universal claims that they can articulate who they are locally.

One major problem with discussions of Vietnam (and more generally of Southeast Asia) is that 'Chinese culture' is often assumed to be monolithic. In fact, the history of the Chinese empire has been a continual process of localised adaptations to the imperial model, which itself evolves over time. Thus, for example, anthropologists and historians studying death ritual in China will make a distinction between orthodoxy and orthopraxy as a way of trying to understand localised variations on imperially ordained funeral procedures. ${ }^{23}$ Or indeed, we can observe the emergence among some literati of racially inflected ideas of 'Chineseness' in reponse to Mongol and Manchu conquest, while others insisted on Confucian universalism. ${ }^{24}$ In other words, in China, too, there has been an ongoing discourse between universalism and particularism, always expressed in distinctly Sinitic terms. Moreover, what is consistently ignored by Vietnam scholars is the ethnic Han response to foreign conquest, and the complex discourse over ethnicity at the top of the Chinese state during Manchu rule, ${ }^{25}$ and the fact that up until its collapse in 1910 the Ching Dynasty was considered by a significant number of Chinese to be 'foreign'.

Furthermore, Vietnam scholars appear to associate Sinicisation exclusively with Confucianism and state-building, whereas an absolutely fundamental part of Sinitic popular and elite culture is Taoism and the wide-ranging set of beliefs and practices which flow from it - geomancy, fortune-telling, medical practices, and so on. Regardless of how 'Confucianised' the peasantry were, we can be certain that these popular beliefs ran deep among Vietnamese and connected them, as they still do today, to a wider East Asian cultural universe. This inattention to Taoism by scholars of Vietnam is puzzling, especially as the spread of this ideology has arguably been one of the key cultural practices used to transform the various peoples ruled by the empire into something

22 Ibid., p. 151.

23 For example, Evelyn Rawski and James L. Watson, Death Ritual in Late Imperial and Modern China (Berkeley: University of California Press, 1988). See also the important debate between Evelyn Rawski and Ping-Ti Ho: Evelyn Rawski, 'Reenvisioning the Qing: The Significance of the Qing Period in Chinese History', The Journal of Asian Studies [henceforth JAS], 55, 4 (1996): 829-50; and Ping-Ti Ho, 'In Defense of Sinicization: A Rebuttal of Evelyn Rawski's "Reenvisioning the Qing"', JAS, 57, 1 (1998): 123-55. The latter emphasises conventional wisdom concerning the gradual spread of Han norms, while Rawski places greater stress on the feedback effect of other cultures, such as the Manchu, on Han culture.

24 Prasenjit Duara, Rescuing History From the Nation: Questioning Narratives of Modern China (Chicago: University of Chicago Press, 1995), pp. 57-60.

25 See, for example, Rawski, 'Reenvisioning'; Mark C. Elliott, 'Manchu Widows and Ethnicity in Qing China', Comparative Studies in Society and History, 41, 1 (1999): 33-71; and Nicola Di Cosmo, 'Manchu Shamanic Ceremonies at the Qing Court', in State and Court Ritual in China, ed. Joseph P. McDermott (Cambridge: Cambridge University Press, 1999), pp. 352-98. 
called Chinese.

As part of the assertion of a pure 'Chinese' model versus a hybrid Vietnamese one, Vietnam scholars often assume a 'Confucianised' patriarchal Chinese peasantry, but as far back as 1961 Maurice Freedman (himself a pioneer of lineage studies in China) warned against simplistic assumptions concerning ordinary Chinese: 'At the other end of the social scale the family was, so to speak, scarcely Confucian. Poverty and powerlessness produced, instead of a strong patriarch, a weak father. ${ }^{26}$ Furthermore, the 'Chinese family' is assumed to be rigidly patrilineal, whereas modern studies have shown the importance of affinal relations and the continuing contact between daughters and their original families. ${ }^{27}$ Furthermore, local practices of delayed marriage and marriage resistance among Han have been documented, with an associated suggestion that this may arise out of prior Zhuang practices. ${ }^{28}$

Probably one of the most unquestioned dogmas of Vietnamese studies to date has been the alleged 'higher status' of Vietnamese women compared with their 'Chinese' counterparts. When such claims are examined closely, however, one becomes aware of the paucity of studies on women in Vietnamese history and the flimsiness of such assertions..$^{29}$ Moreover, most of these analysts ignore scholarship on Chinese women, and appear to be unaware of the complex origins of some of the restrictions on Han women. For example, it can be argued that it was the Mongol Yuan dynasty, with its own view of 'women and their dowries as household property', that 'rewrote laws to make it virtually impossible for a woman to leave the household of her first marriage... ${ }^{30}$ Such arguments confound those of Ta Van Tai, whose studies of Vietnamese legal codes have formed the bedrock of many of the claims made about the status of Vietnamese women. Ta, for instance, has written that while 'the Le Dynasty pursued a genuinely Vietnamese tradition and upheld women's civil rights on an equal footing with those of men, the Nguyen Dynasty, copying the Ch'ing Code, paid as little attention to women's interests as did all the Chinese dynasties.'. ${ }^{31}$

Typically, we have here the model of a static China and a dynamic Vietnam. However, once we place Chinese culture and society back in history and acknowledge its changes and diversity then much of the discourse constructed by scholars of Vietnam collapses. David Faure, for example, has shown the intimate connection between the expansion of Han state power and the construction of large lineages in the south, an approach which accords with more recent anthropological approaches to kinship which do not see it as some kind of independant cultural variable but as part of larger

26 Maurice Freedman, 'The Family in China, Past and Present', reprinted in The Study of Chinese Society: Essays by Maurice Freedman, ed. G. William Skinner (Taipei: SMC Publishing Inc. 1994), pp. 240-54; this essay was first published in Pacific Affairs, 34, 4 (1961): 323-36.

27 See, for example, Ellen R. Judd, 'Niangjia: Chinese Women and Their Natal Families', JAS, 48, 3 (1989): 525-44; and David Schak, 'Bilaterality in Chinese Kinship', China Information, 12, 4 (1988): 21-43. 28 See Janice Stockard, Daughters of the Canton Delta (Stanford, CA: Stanford University Press, 1989).

29 Typically one is treated to hyperbolic claims like the following : 'Vietnamese women, in the deep recesses of their nation's history, played an openly powerful role and countered ... Confucian male power ... One could say that Vietnamese women are the main inheritors of indigenous traditions in Viet Nam...'; see Stephen O'Harrow, 'Vietnamese Women and Confucianism', in 'Male' and 'Female' in Developing Southeast Asia, ed. Wazir Jahan Karim (Oxford/Washington DC: Berg Publishers, 1995), p. 175. 30 Elliott, 'Manchu Widows', p. 53.

31 Ta Van Tai,'Women and the Law in Traditional Vietnam', The Vietnam Forum, 3 (Winter-Spring 1984): 42 . 
structures, including political and economic ones. ${ }^{32}$ A later collection by Faure and Liu Tao Tao also underlines the regional cultural diversity of peoples within the boundaries of modern China, in particular Han diversities. ${ }^{33}$

Perhaps the one Vietnam scholar who does not lose sight of the fundamental Sinitic nature of Vietnam is Alexander Woodside, who states at the beginning of his book on the Nguyen dynasty that the 'Vietnamese people were sinicized centuries before Chinese culture had even been definitively consolidated in areas that are today considered part of China proper... ${ }^{34}$ For someone with this approach the diversity documented by Liu and Faure would hardly come as a surprise. In the book Woodside certainly acknowledges the impact of Southeast Asia on the Vietnamese, in particular through the Cham and the Khmer. Nevertheless, he does warn that 'it is dangerous to be deterministic in ascribing all differences between Vietnam and China to the Southeast Asian environment'. ${ }^{35} \mathrm{~A}$ modern look at China will find that such cross-cultural interaction and borrowing is common throughout the empire, and thus we can see the impact of Manchu and Mongolian culture in the north, and Zhuang and other minorities in the south, ${ }^{36}$ and so on. Looked at in this light, the counterposition of a hybrid Vietnam to an allegedly pure 'China' becomes less and less convincing.

What is absolutely fundamental to Vietnamese history is the formation of a separate 'Confucian monarchy' whose state provided an arena for the articulation of difference at the highest level. This caused, as Woodside writes, a centralisation of political memory in which 'history writing became a major form of oppositional "boundary maintenance" by Vietnamese and Korean state centers and their elites against Chinese hegemony. ${ }^{37} \mathrm{~A}$ text compiled in the eighteenth century, for example, 'produced an inventory of lost Vietnamese books and archives, going back to 1026 A.D., many of which had been destroyed or carried away by Chinese invaders. This was "injustice collecting" on a formidable scale... This memory would be transmuted later into twentieth century nationalism. ${ }^{38} \mathrm{Had}$, for example, the Cantonese formed a separate state, similar processes would have occurred and Cantonese today would be considered as a separate language in the Chinese language family and not as a 'Chinese dialect', and a distinct nationalist history of these people would have been produced. Why it did not happen is not what

32 David Faure, 'The Lineage as a Cultural Invention: The Case of the Pearl River Delta', Modern China, 15, 1 (1989): 4-36. For an argument that problematises the centrality of cognatic kinship in studies of Southeast Asia see Cognation and Social Organization in Southeast Asia, ed. Jeremy Kemp and Frans Husken (Leiden: KITLV Press, 1991).

33 Unity and Diversity: Local Cultures and Identities in China, ed. Liu Tao Tao and David Faure (Hong Kong: Hong Kong University Press, 1996).

34 Alexander Woodside, Vietnam and the Chinese Model (Cambridge, MA: Harvard University Press, 1971, p. 7.

35 Ibid., p. 22.

36 For example, Eric Boudot, writing on textiles in China, shows not only how the minorities borrowed fabrics and styles from the Han, but also how the Han borrowed from the minorities; see his 'Minority Costumes and Textiles of Southwestern China', Orientations, 25, 2 (1994): 59-66.

37 Alexander Woodside, 'Territorial Order and Collective-Identity Tensions in Confucian Asia: China, Vietnam, Korea', Daedalus, 127, 2 (1998): 199.

38 Alexander Woodside, 'Vietnamese History: Confucianism, Colonialism and the Struggle for Independence', The Vietnam Forum, 11 (Spring-Autumn 1988): 30. Such 'injustice collecting' remains equally vivid in Chinese culture today with its elaborate discourse on 'national humiliations'. In May 2000 Hong Kong was in uproar over the sale by Christie's auction house of artifacts looted from the Imperial Palace by British and French troops. 
concerns us here - but Vietnam does provide the comparative historian with some idea of what could have happened.

Recently, historian Nguyen The Anh has inveighed against the 'preoccupation to prove the homogeneity and coherence ${ }^{39}$ of Vietnam and its history, and the denial of any internal ethnic or regional heterogeneity by subsuming them under a rhetoric of unity in the face of outsiders. Keith Taylor, too, has spoken of the need to 'breathe free of the strangling obsession with identity and continuity mandated by the nationalist faith that has animated virtually every twentieth-century historian who has written about Vietnam, including myself... ${ }^{30}$ What they, and Wolters too, wish to pursue are increasingly textured, localised analyses of Vietnamese historical and cultural materials, free of a priori assumptions. The rewards of this re-orientation have begun to flow in. ${ }^{41}$

I wish to add to this repositioning the suggestion that once one concedes that the model of a pure Confucianised China has collapsed, then Vietnam cannot be construed as a paler or smaller version of it, but simply one variation on an East Asian cultural theme. ${ }^{42}$ The reintegration of Vietnam into the East Asian cultural area, at least intellectually, is crucial for breaking the nationalist stranglehold over Vietnamese studies and for dynamiting the gridlock of 'national uniqueness'.

\section{Anthropology and Southeast Asia}

The debates over the historical contours of Southeast Asia have reflected the increasingly close relationship between history and anthropology, with each turning to the other for both empirical and theoretical assistance. Recent overviews of anthropological studies of Southeast Asia have all raised the issue of the relationship of the local to the regional, and indeed to the global. John Bowen, while acknowledging the unities that historians have identified in the region, claims that Southeast Asia has been 'the place where interpretive approaches to culture have reigned', and where 'it is the ubiquity of publicly displayed cultural forms that gives the region its distinctive aura." ${ }^{44}$ These interpretive approaches, epitomised by Clifford Geertz, have, however, treated

39 Nguyen The Anh, 'Quelques remarques sur l'état des études historiques sur le Vietnam', The Vietnam Review, 3 (1997): 469.

40 Keith Taylor, 'Surface Orientations in Vietnam: Beyond Histories of Nation and Region', JAS, 57, 4 (1995): 6.

41 See Essays Into Vietnamese Pasts, ed. K.W. Taylor and John K. Whitmore (Studies on Southeast Asia, Ithaca, NY: Cornell Southeast Asia Program, 1995).

42 As for 'Hinduised' Southeast Asia, I. W. Mabbett as far back as 1977 had warned 'that "Indian culture" is not a monad. It is on the contrary a plurality of traditions, or of levels of vocabularies within a tradition, or a portmanteau term for a number of different total cultures with shared historical ancestry' ('The "Indianization" of Southeast Asia: Reflections on the Prehistoric Sources', The Journal of Southeast Asian Studies, 8, 2 [1987]:160). Sanskritisation in Southeast Asia was not so different to what occurred in India itself, where it continually accommodated to local traditions. 'There is therefore a false dichotomy between Indian cultural imperialism and local autonomy. Local religious cults remained strong in India, assuming new forms, just as they did in Southeast Asia ... for culturally Southeast Asia became nearly as "Indian" as parts of India, while politically there was no such thing as India' (p. 161).

43 One should say that the same strictures would apply to studies of China where Sinocentrism is still a powerful force. Thus studies of local cultures like that of Liu and Faure are content to rest within the boundaries of modern China, and show no obvious awareness of the possible comparative relevance of Vietnam.

44 John R. Bowen, 'The Forms Culture Takes: A State-of-the-Field Essay on the Anthropology of Southeast Asia', JAS, 54, 4 (1995): 1047-8. 
cultural forms too semiotically as texts to be read by the anthropologist. The new twist to this interpretive mode, Bowen says, de-centres the anthropologist and focuses on the multiple 'creation of meanings by differently situated actors, meanings that are often in conflict with each other and that are not always resolvable to an internally coherent structure ${ }^{35}$ He points out that it is impossible to pretend, as perhaps anthropologists once did, that the local is not shot through with translocal influences.

The desire to know what ordinary people think of their culture no doubt accounts for the greater emphasis in Wolters' revised text on how people make sense of their world, and for his analysis of local literature. Indeed, this demand has produced some ingenious and subtle attempts to read all kinds of texts from the past in order to wring further meanings from them. ${ }^{46}$ But, according to Bowen's criteria, historians must always fall short, because they do not have access to the polyphony of the past. A simplistic demand for 'voices', however, drastically impoverishes approaches to culture because we know that much of our learning and understanding is not expressed in language, nor is it language-like. ${ }^{47}$ This, of course, entails a move back in the direction of at least Geertzian-style interpretation of culture. Of course, certain elements of a culture may be 'contested', but there are usually shared ground-rules in the process of contestation. As Aram Yengoyan remarked some time back in a book dedicated to the work of Geertz:

A dialectic theory of constraints assumes that each culture emphasises specific cultural spheres ... In some cases, one cultural form may override other structures, but in most cases it appears that constraints stem from varied spheres of culture and constrict and curtail the evolution of specific practices. At the same time, the interplay of constraints within the social realm may determine creative cultural responses, specific in form to the culture. ${ }^{48}$

These constraints, of course, are also in operation when specific cultures adopt, borrow, assimilate externally-generated cultural forms and practices. This is precisely Wolters argument about self-Hinduisation in Southeast Asia, where Sanskrit ideas were made sense of in terms of already existing ideas of prowess. But the difficult issue is, once these ideas have been taken on, what transformations do they engender, and at what point does a qualitatively new structure come into existence?

Cultural ideas and artifacts may be borrowed to bolster old ideas. So, if we observe the following picture of two Lao aristocratic women in Luang Prabang in costumes made of Chinese silk, facing a table with a Chinese-style tablecloth - and note that Lao are renowned for their fine silk weaving - then it becomes clear that these traditionally scarce goods are being used by the elite to display elite status. Or, alternatively, borrowings may be used to express new ideas within apparently traditional ritual structures. One thinks of the use of the 'Western' white wedding dress in the context of a modern Chinese wedding ritual. The ritual itself outwardly conforms to 'tradition', but the dress is a 45 Ibid., pp. 1049-50.

46 See, for example, Eleanor Mannika, Angkor Wat: Time, Space, and Kingship (Honolulu: University of Hawaii Press, 1996).

47 Cognitive anthropology, among other strands, makes this clear; see Maurice E.F. Bloch, How We Think They Think (Boulder, CO: Westview Press, 1998).

48 Aram Yengoyan, 'Cultural Forms and a Theory of Constraints', in The Imagination of Reality: Essays in Southeast Asian Coherence Systems, ed. A.L. Becker and Aram A. Yengoyan (Norwood, NJ: ABLEX Publishing Corporation, 1979), p. 328. 
marker of modern, romantic love, and of modern marriage. In other words the ritual, the culture, has reconfigured itself. The dress and what it signifies do not constitute simply an addition, but rather are part of a new cultural matrix. Terry Rambo makes a similar point in his article on how the Chinese-derived ao dai came to be seen as 'Vietnamese national dress' for women, when other items of dress were rejected, while Neil Jamieson shows how attitudes to haircuts and writing systems were reconfigured as more or less 'genuinely Vietnamese ... as part of an evolving context at some particular historical point...' Both emphasise the way cultural elements are part of whole structures, and derive their meaning from a total context, which itself evolves and changes over time. ${ }^{49}$

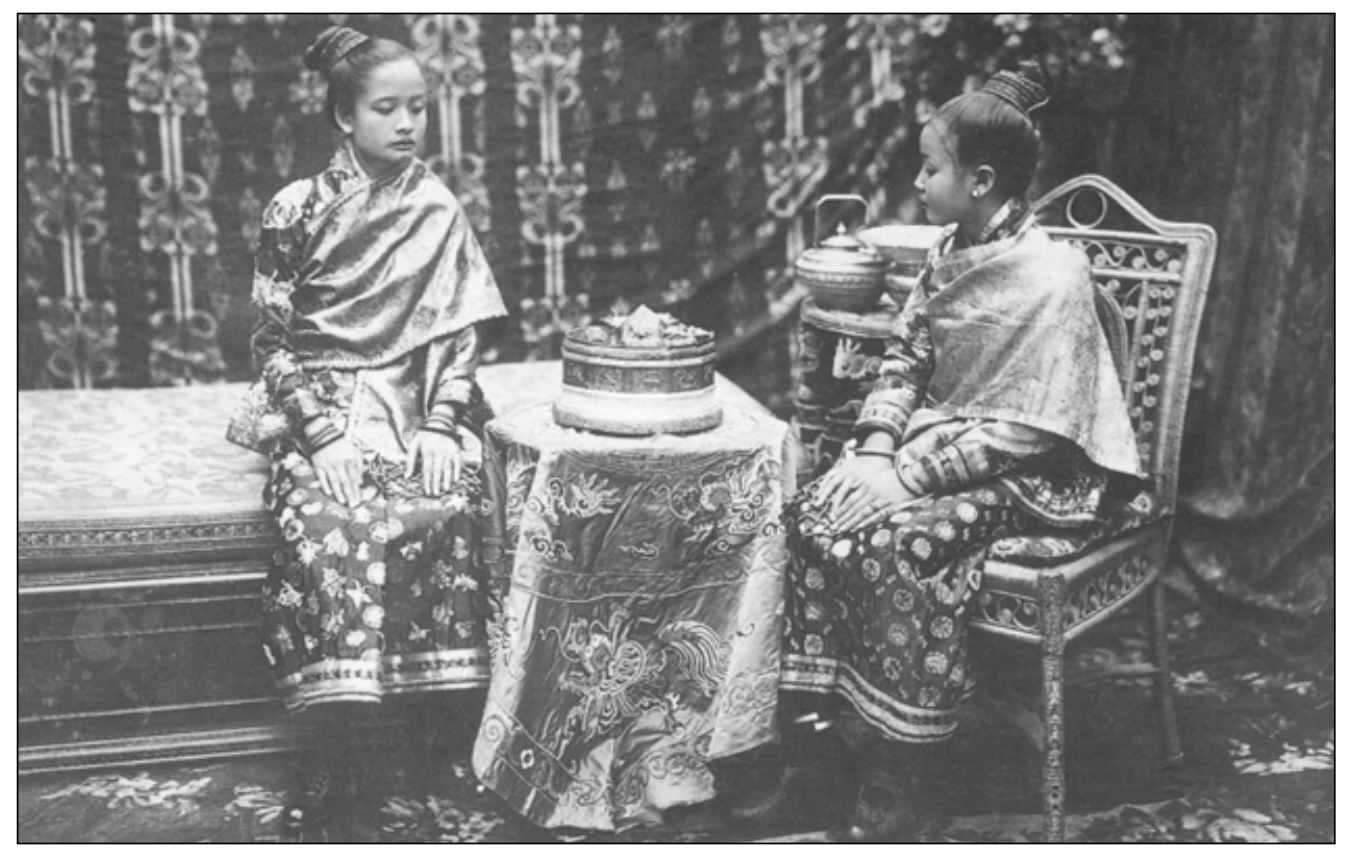

Methodologically the debate over borrowings for historians parallels debates over globalisation among contemporary anthropologists and others. Marshall Sahlins has released salvo after salvo into this debate to combat an anthropology that sees local cultures falling before the juggernaut of globalisation. He is intent on stressing how local cultures 'indigenize modernity' according to a local cultural logic:

49 Terry Rambo, 'Black Flight Suits and White Ao-Dais: Borrowing and Adaptation of Symbols of Vietnamese Cultural Identity', in Borrowings and Adaptations in Vietnamese Culture, ed. Truong Buu Lam (Southeast Asian Paper No. 25, Manoa: University of Hawaii Center for Southeast Asian Studies, 1987), pp. 115-23; Neil Jamieson, 'Relata, Relationships, and Context: A Perspective on Borrowed Elements in Vietnamese Culture', in the same volume, p. 129. Vietnam scholars who wish to assert that there is some kind of 'cultural core' to Vietnam usually end up describing isolated cultural features, rather than contextualised relationships. See, for example, John K. Whitmore, 'Foreign Influences and the Vietnamese Cultural Core: A Discussion of the Premodern Period', in the same volume, pp. 14-16. Shawn McHale, “"Texts and Bodies": Refashioning the Disturbing Past of Tran Vietnam (1225-1400)', Journal of the Economic and Social History of the Orient, 42, 4 (1999): 494-515, is the latest attempt to add yet another cultural feature, body tattooing, as a mark that differentiates Vietnamese from Chinese. 
This dialectic of similarity and difference, of convergence of contents and divergence of schemes, is a normal mode of cultural production. It is not unique to the contemporary globalizing world. On the contrary, its precolonial and extra-colonial occurrences help explain the colonial and postcolonial... No culture is sui generis, no people the sole or even the principal author of their own existence. ${ }^{50}$

Sahlins' main interest is 'tribal' peoples who supposedly were destined to be gobbled up by modernity; he points out that Eskimos continue to hunt, albeit now using aeroplanes and guns. The problem with Sahlins is that he appears reluctant to recognise that this may entail a fundamental shift in the culture. He generally avoids thinking about the transformations that have occurred in state societies like Vietnam or Thailand, which are considerable, and here Wolters' perspective is much better, though he, too, advances the idea of cultural continuity through 'indigenization'.

One might like to go along with Wolters' claim that Southeast Asia is entering its neo-mandala age because of the cultural transmission of a particular cognitive structure. Tambiah has argued for continuity within the changes undergone by the Thai state because of the continuing symbolic role of the king. ${ }^{51}$ And I have argued for the continued salience of similar symbolic structures in Laos even after the king's overthrow. ${ }^{52}$ Nevertheless, it would clearly be a mistake to think that, for example, the Thai state today is simply some updated variant of the mandala state. Fundamental changes have taken place in the whole social structure, not least because of nationalism.

An abiding methodological flaw in debates about Southeast Asia, partly driven by nationalism, has been the search for allegedly 'deeper' underlying features of these societies, over which are layered less 'deep' foreign imports. ${ }^{53}$ But we need to discard this metaphor of layering in favour of a theory of cultural constraints suggested by Yengoyan. The layering metaphor has been most powerful in studies of Vietnamese history where strenuous attempts have been made to uncover a non-Sinitic, allegedly autonomous cultural base. But even in his 1983 study Taylor realised he was chasing a chimera: 'it is not easy to define what this "indigenous tradition" was in specific terms, for the indigenous content had been transformed during the centuries of Chinese rule. ${ }^{54}$ As Rambo mischievously observes, even if one were able to 'reconstruct their pre-Sinitic culture, we end up with something not authentically Vietnamese but instead with something that modern Vietnamese themselves would label as "savage"... ${ }^{55}$

Recently Taylor has attempted to bypass nationalist narratives and deny deep cultural structures by going radically local. Indeed, his current approach is not so distant from that articulated by Bowen when he writes that 'my reading of the archive convinces me that human experience is ultimately episodic, not evolutionary, and that all histories, whatever the surface upon which they are formed, are equally discontinuous'. ${ }^{56}$ Taylor's

50 Marshall Sahlins, 'Two or Three Things That I know About Culture', Journal of the Royal Anthropological Institute (NS), 5, 3 (1999): 411.

51 Stanley J. Tambiah, World Conqueror, World Renouncer (Cambridge: Cambridge University Press, 1976), pp. 525-7.

52 Grant Evans, The Politics of Ritual and Remembrance: Laos Since 1975 (Chiang Mai: Silkworm Books, 1998).

53 Craig Reynolds, has made a similar point in his article 'A New Look at Old Southeast Asia', JAS, 54, 2

(1995): 419-46.

54 Taylor, Birth of Vietnam, p. 264.

55 Rambo, 'Black Flight Suits', p. 121.

56 Taylor, 'Surface Orientations', p. 970. 
intention is to go beyond even Prasenjit Duara's attempts to 'rescue' previously suppressed heterodox narratives of the Chinese nation from nationalism (this is Nguyen The Anh's objective for Vietnamese history as well). Such historians, says Taylor, still privilege 'the nation' as an historical subject, whereas he wishes 'to imagine the past as if the nation is not the subject of history, whether to be honored in itself or by appeal to its regions. ${ }^{57}$ Not surprisingly, Taylor finds himself questioning all macro-categories, whether they be common languages, common cultures, or culture areas.

Taylor's essay is stimulating to read and his radical deconstruction of the received categories of historical writing about Vietnam is a breath of fresh air in a field already seriously starved for oxygen. No doubt it will open up new avenues for research, and indeed I could not agree more with him about the need to think about the past without the distorting lens of the nation. But, appeals to apparently unconstrained 'creative' subjects are unsatisfying. As Marshall Sahlins argues, pure agency is no substitute for cultural structure: 'Although in theory structure is supposed to be a concept antithetical to history and agency, in practice it is what gives historical substance to a people's culture and independent grounds to their action. Without cultural order there is neither history nor agency. ${ }^{58}$

\section{Culture areas and regions/ecumenes as discursive spaces}

The exploration of culture areas fell into abeyance in anthropology along with the parallel programme of comparative analysis partly because of confusions and disagreements about how 'coherent' such areas should be and what 'traits' to compare. It had been essentially a positivist programme that assumed the unproblematic comparison of theoretical objects such as 'kinship' or 'economy' across cultures. As Ladislaw Holy writes, 'It was not recognized that it is discourses rather than objective forms that are compared. ${ }^{59}$ Comparative research can proceed, of course, not only by noting similarities but also by registering differences with the aim of bringing cultural specificity more sharply into focus. If we agree that comparison is the basis of cognition then it is hard not to conclude that most if not all fields of enquiry are at least implictly comparative.

The identification of cultural areas suggests that the comparison of cognate societies can be a source of useful knowledge, in a heuristic sense if not an explanatory one. Sydney Mintz argues that at a certain level particular regions make up congruous historical and conceptual units and any attempt to abstract discrete societies from them inevitably produces distortions in our understanding. ${ }^{60}$ Not only do states and societies within such regions influence each other through a process of interaction, they exchange aspects of culture and indeed share these across societal and political boundaries. Linguists, for example, have encountered similar issues when grappling with the idea of linguistic areas. While the branching tree metaphor is used for establishing language

57 Ibid., p. 952.

58 Sahlins, 'Two or Three Things', p. 412.

59 Ladislaw Holy, 'Introduction: Description, Generalization and Comparison: Two Paradigms', in Comparative Anthropology, ed. Ladislaw Holy (Oxford: Basil Blackwell, 1987), p. 8.

60 Sydney W. Mintz, 'Enduring Substances, Trying Theories: The Caribbean Region as Oikoumene', Journal of the Royal Anthropological Institute, 2, 2 (1995): 297. See also Adam Kuper, 'Introduction', in Conceptualizing Society, ed. Adam Kuper (London and New York: Routledge, 1992), p. 13. 
genealogies and 'families', adjacent non-related languages may play an equally important role in linguistic change.$^{61} \mathrm{By}$ analogy, culture areas are a bit like language families, while regions/ecumenes are like language areas.

In a review of anthropological work in another area, Melanesia, R. Laderman has also advocated the utility of the 'culture area' concept to counter the growing dissatisfaction of anthropologists with exploring the diversely 'local' while facing the obvious growing presence of the global. Like me, she naturally does not want this idea associated with the fixed framework used for classifying museum exhibits. But, she argues, whatever the problems with some of the original theories of culture areas, the 'key point is that culture areas were, from the outset, less simply about areas than about culture theories. They operated as heuristic bases for generalization; they organized ethnographic particulars for theoretical and comparative ends.' Furthermore, in an argument that applies equally to Southeast Asia, she points out that whatever the critiques offered by contemporary interpretivist anthropology of past practices, 'we still live with versions of the same maps and their associated ethnographic discourses. ${ }^{62}$ This latter observation applies to Bowen, as it does to Mary Margaret Steedly's follow-up survey of culture theory in Southeast Asia where, despite her claim that it is 'arguably the most insubstantial of world areas, ${ }^{63}$ she continues to use it as her field of reference. This underscores Laderman's point that such areas have established themselves 'as discursive frameworks for organizing disciplinary practices, ${ }^{64}$ even if part of their origin lies in colonial or imperial imaginings.

In the conceptual debates over Southeast Asia we can see some perennial theoretical issues. On the one hand, there are those who lean towards a view of culture as an underlying generative structure, while on the other hand, we have those who see endless cultural variation. As Holy argued some time ago,

It seems that for some time to come both basic assumptions will be resorted to in comparative analyses. Those who prefer to see variations as endless perspectives point out that the notion of the generative power of the underlying structure can be rescued from its rigid formalism when more attention is paid to the way actors themselves conceptualise, use, manipulate and interpret the phenomena which the structure is assumed to generate. Those who advocate the necessity of the notion of an underlying structure point out that the endless perspectives are in fact finite and that only some perspectives from the endless multitude of the possible ones are adopted. To account for that some notion of structural regularity has to be entertained. The limitation on perspectives can be accounted for by discovering the structural principles which have been recognized by any particular culture in question. ${ }^{65}$

Recent theoretical discussions would indicate that perhaps this dialectic is interminable as writers snipe at each other from apparently contrasting positions. But, in

61 Theodora Bynon, Historical Linguistics (Cambridge: Cambridge University Press, 1977), and William A. Foley, Anthropological Linguistics: An Introduction (London: Blackwell, 1997), p. 391.

62 R. Laderman, 'Globalisation and the Future of Culture Areas: Melanesianist Anthropology in Transition', Annual Review of Anthropology, 27 (1998): 431.

63 Mary Margaret Steedly, 'The State of Culture Theory in the Study of Southeast Asia', Annual Review of Anthropology, 28 (1999): 434.

64 Laderman, 'Globalisation', p. 428.

65 Holy, 'Introduction', p. 18. 
fact, what we really see in all of these writers is a feature highlighted in John Hall's recent book on Cultures of Inquiry, where he points out that not only do various theoretical approaches overlap, but each is implicated in the other's discourse. While each approach attempts some kind of totalisation,

Any totalization gains coherence at the expense of the aspects that it omits, suppresses, or subordinates, and it is vitally dependent on these textual solutions. Therefore, a 'supplement' may be developed to identify absences - those things not contained by the attempted totalization. There is always 'play' between totalization and supplement, and, in turn, a tension between this textual play and history. ${ }^{66}$

Examples of such totalisations are culture areas, nations, or local or global studies, to name just some of the concepts that I have referred to. None, however, are able to have the last word. Indeed, what Hall identifies as 'supplements' can be explored by the same author and in the same text as a subordinate parallel discourse. In a sense, one can see this in Wolters' desire to make both region-wide and local analyses.

The heuristic importance of notions of a culture area, or of a region/ecumene, is that they enable and establish levels of analysis above the nation-state. Studies of local diversities within nation-states can, of course, undermine the state's totalising claims too. The nation-state's main aim, naturally, has been to try to create the illusion and the reality of cultures being bounded by national borders. My critique of the practices of the state does not intend, however, to claim that totalisation at the level of the nation-state is somehow false or unreal. As a discursive reality it is as real as any of the others. Indeed, through the deployment of the full resources of the state and its legitimating apparatuses this level has become hegemonic (and remains so despite 'globalisation' claims), and as such it tries to induce analytic closure.

Other discursive realities challenge this hegemony and therefore produce an openness to which the culture of scientific discourse is committed. Culture areas focus on cognate cultures and societies, such as Theravada Buddhist societies, and can bring to light intriguing commonalities. ${ }^{67}$ Failure to take the idea of culture areas seriously can, on the other hand, lead analysis astray, as it has done for so long with studies of Vietnam which have been bogged down by a nationalist agenda. Of course, the research encouraged by the use of concepts of culture area and ecumenes is comparativist, and requires the exploration of similarities and differences with the aim not of building causal models but of charting thematic issues, 'deep analogies', ${ }^{68}$ and contextual meanings. For those interested in such an enterprise in Southeast Asia studies, the revised

66 John R. Hall, Cultures of Inquiry: From Epistemology to Discourse in Sociohistorical Research (Cambridge: Cambridge University Press, 1999), p. 21.

67 See Grant Evans, 'Introduction: What Is Lao Culture and Society?', in Laos: Culture and Society, ed. Grant Evans (Chiang Mai: Silkworm Books/ Seattle: University of Washington Press, 1999).

68 The term is from Arthur L. Stinchcombe, Theoretical Methods in Social History (New York: Academic Press, 1978). 
edition of Wolters' book remains seminal. 